\title{
De(materializacja) pracy i „wolność” zawodu projektanta
}

\begin{abstract}
The main object of the article is an attempt to answer the question about the limits of freedom and independence of professional designers. It seems to be important, especially now, when we can observe how creative industries provide to innovative development of society and to competitive advantage. Is it possible to have autonomy being a designer? Referring to B. Bourdieu's field theory and idea of socially responsible design (Papanek, 2012) it will be shown the context of this profession as a balance of power between the individual actors (designers, client, users, society) in the field of design. Object of the present text is description of the designer's profession in relation to the subjectively perceived degree of professional independence. The example used to analyze this issue are interviews conducted among British designers from Helen Hamlyn Centre for Design.
\end{abstract}

\section{Keywords:}

independence, occupation, designers, field of design, Bourdieu

1 Paulina Rojek-Adamek, Katedra Socjologii Komunikowania, Instytut Filozofii i Socjologii, Uniwersytet Pedagogiczny w Krakowie, Polska, projek@interia.pl. 


\section{WOLNOŚĆ I DEMATERIALIZACJA PRACY}

„Człowiek jest skazany na to, by był wolny”, pisali egzystencjaliści. „Człowiek wciąż musi wybierać, decydować, a jego decyzje są brzemienne w skutki nie tylko dla niego samego, ale również dla innych. Człowiek jest zatem wolny, czy tego chce, czy nie. Wolność w takim ujęciu oznacza więc nie tyle przywilej, co raczej ciężką konieczność” (Tatarkiewicz, 1995, s. 352). Mówiąc o wolności myślimy przede wszystkim o granicach wyznaczających przestrzeń życiową jednostki, w której organizuje ona relacje społeczne z prawem do podejmowania wyborów. Jednym z wymiarów, który odgrywa szczególną rolę w życiu większości ludzi, jest sfera zawodowa. Praca to kategoria, którą można rozpatrywać w kontekście budowania więzi społecznych w ramach podziału pracy, wyłaniania się nowych form organizacji, systemu wartości (por. m.in. Durkheim, 1999; Weber, 1994; Simmel, 1997), ale również jako kategorię ekonomiczną, decydującą o miejscu jednostki w świecie cenionych dóbr i w świecie zróżnicowania społecznego. Mając świadomość, że jest środkiem zapewniającym w mniejszym lub większym stopniu powodzenie życiowe, mówienie o „wolności” staje się kluczowe. W ramach sfery pracy można postrzegać wolność w ujęciu dychotomicznym: jako wolność (do) pracy oraz jako wolność w pracy. Wolność pracy traktuje się jako kategorię prawną, której podstawy znajdują odzwierciedlenie w postaci zapisów odnoszących się do praw jednostki w ogóle (np. Konstytucja Rzeczypospolitej Polskiej, która zalicza pracę do kategorii wolności i praw socjalno-ekonomicznych obywateli). Wolność w pracy jest zaś wypadkową obiektywnych uwarunkowań wykonywania danego zawodu oraz subiektywnych odczuć, systemów wartości, orientacji i postaw wobec możliwości dokonywania „słusznych” wyborów. Przemiany pracy pokazują, że dla współczesności symptomatyczne jest wiązanie pracy już nie tylko z wytwarzaniem żywności czy przedmiotów, ale z operowaniem abstraktami i ideami. Obserwowane zjawisko określa się mianem „dematerializacji pracy”, choć należy podkreślić, że wytwory działalności mogą przyjąć postać materialną (np. generowanie pomysłów dotyczących budowania poczucia identyfikacji z miejscem w efekcie przyjmuje postać konkretnych rozwiązań np. w obrębie projektowania przestrzeni). „Praca dematerializuje się, zarówno jeśli chodzi o wytwarzane przedmioty, jak i relacje między pracownikami i ich środowiskiem oraz interakcje między nimi. Co więcej, zmianom natury pracy i sposobów pracowania towarzyszą głębokie przemiany relacji między pracą i aktywnością poza pracą. Charakteryzuje je zanik tradycyjnych granic, które oddzielały czas i przestrzeń związane z aktywnością poza pracą. Praca wychodzi z fabryk i biur, zawłaszczając także przestrzeń prywatną oraz miejsca publiczne. Dystynkcja między miejscem pracy i innymi sferami życia, 
między czasem pracy a czasem nie-pracy, tak niegdyś wyraźna, staje się coraz bardziej płynna” (Chojnowska, cyt. za: Marody, Giza-Poleszczuk, 2004, s. 251). Proces ten pociąga za sobą szereg konsekwencji, zarówno pozytywnych, jak i negatywnych. Skoncentrowanie na wiedzy pracownika i pozostawienie mu całkowitej swobody w zarządzaniu czasem pracy jest niewątpliwie zaletą. Oderwanie jednak od miejsca pracy, elastyczny system zatrudnienia, brak wsparcia ze strony współpracowników (np. związków zawodowych) sprawiają, że coraz trudniej o poczucie bezpieczeństwa, a to w efekcie może dawać tylko pozory wolności. Wydaje się, że jedną z grup zawodowych, której wewnętrzne przemiany mogłyby stać się dobrym przykładem dla ukazania złożoności problematyki niezależności zawodowej, są współcześni projektanci.

\section{DESIGNER - O ETYCE W PROJEKTOWANIU}

W języku angielskim słowo designer nie budzi większych wątpliwości dla zainteresowanych tematyką. W języku polskim designer to projektant. Choć dyskurs publiczny „udomowił” słowo designer i nie sposób oderwać się od jego obecności, to w odniesieniu do profesjonalnego ujęcia - wynikającego m.in. z Polskiej Klasyfikacji Wyrobów i Usług (PKWiU)² - w języku polskim powinno się raczej mówić o specjalistach w zakresie projektowania wzornictwa (tkanin, odzieży, obuwia, biżuterii, mebli i pozostałego wystroju i dekoracji wnętrz), projektowania przemysłowego, projektowania graficznego (wyłączając fachowców z zakresu projektowania i programowania stron internetowych, projektowania architektonicznego czy projektowania inżynierskiego). W rozumieniu przyjętym w tekście designer/projektant to osoba ,uprawiająca profesję intelektualną, a nie po prostu rzemiosło lub świadczenie usług dla przedsiębiorstw. [...] [ich praca] odnosi się nie tylko do strony wizualnej (estetycznej, artystycznej) produktu czy usługi (jak to często potocznie jest rozumiane), ale integruje różne obszary, takie jak kultura, nauka czy technika” (Bochińska, Palczewska, 2008, s. 5). Praca projektanta i jego autonomia zależeć zawsze będą od systemu etycznego, który - jak w wielu zawodach - wyznacza granice dopuszczalnych aspektów działalności. Jednym z przykładowych dokumentów, który ma zastosowanie w odniesieniu do zawodu projektanta, jest Modelowy Kodeks Postępowania Zawodowego Dla Projektan-

2 W obowiązującej PKWiU, Załącznik do rozporządzenia Rady Ministrów z dnia 2015 r. Dz.U. poz. Polska Klasyfikacja Wyrobów i Usług. 
tów Europejskich. Jak czytamy na stronie Stowarzyszenia Projektantów Form Przemysłowych, kodeks ten określa obowiązki projektanta wobec trzech kategorii odbiorców. Do najważniejszych aspektów zalicza się:

- Obowiq̨zki projektanta wobec społeczeństwa, m.in. zobowiązujące projektanta do przestrzegania i rozwijania społecznych oraz estetycznych standardów projektowania, działania w najlepszym interesie ekologii i środowiska naturalnego;

- Obowiq̨zki projektanta wobec zleceniodawcy/klienta, m.in. oznaczające, że projektant powinien działać w interesie klienta - w granicach obowiązków zawodowych, powinien traktować wiedzę na temat planów, metod pracy oraz/albo organizacji firmy klienta jako poufną i nie powinien w żadnym przypadku ujawniać takich informacji bez jego zgody;

- Obowiqzzi projektanta wobec innych projektantów, co m.in. oznacza, że projektant nie powinien w sposób bezpośredni bądź pośredni próbować zająć miejsca innego projektanta pracującego nad zleceniem, przyjmować zlecenia, nad którym pracuje inny projektant bez poinformowania go o tym (http://spfp.org.pl).

Zasady, które przyjmują postać takich kodeksów, są niezwykle ważne. Jednak to, na ile zinternalizowany jest ów zapis, zawsze pozostanie kwestią indywidualną. Przy okazji warto zaznaczyć, że weryfikowanie, czy postępowanie jest etyczne czy nie, również nie należy do zadań łatwych, chyba że dotyczy ono jawnego naruszenia obowiązujących przepisów prawa. Co więcej, etyka w projektowaniu, jak pokazują badania, to także umiejętność empatycznego i humanistycznego podejścia do definiowania potrzeb odbiorców. „Jakkolwiek wszelki design odnosi się do człowieka, to jednak na miano designu humanistycznego nie zasługują wszystkie wysiłki designera. [...] Co najważniejsze, obiekt ujmuje on [humanistyczny design] od strony podmiotowej, to znaczy subiektywnej, od strony sposobu jego doświadczania, przeżywania - z myślą o tym, jak jest doświadczany, czym i jak jest w doświadczeniu, dla doświadczającego go człowieka - w zależności od jego nastawienia, nastrojenia, postawy, punktu widzenia. W języku Floriana Znanieckiego można powiedzieć: humanistyczny design(er) projektuje, nie tylko uwzględniając »współczynnik humanistyczny « (punkt widzenia potencjalnego podmiotu), ale wchodzi w spor o treść, charakter tego współczynnika, gotów przy tym zmienić swój własny punkt widzenia” (Krupiński, 2014, s. 108-109). 


\section{OD RELACJI DO NIEZALEŻNOŚCI - POLE DESIGNU}

Projektanci nie działają w próżni. Na każdym kroku napotykamy świat urządzony przez wyobraźnię, talent projektantów oraz skalę umiejętności zrozumienia indywidualnych potrzeb użytkowników. Ich praca jest tak mocno powiązana z otoczeniem społecznym, że nie sposób oddzielić świat designu od „społeczeństwa designu” (Sztompka, Bogunia-Borowska, 2012). Projektanci działają równocześnie w przestrzeni relacji społecznych o różnym podłożu i nasileniu. Działają w polu, na które składa się zarówno profesjonalny świat designu jak również świat tych, którzy wytwory ich pracy oceniają i wartościują w kategoriach użytkowych, funkcjonalnych czy estetycznych. Kategoria pola wymaga jednak wyjaśnienia. Pole, pisał Bourdieu, jest „ustrukturowanym systemem sił, konfiguracją zdolną do narzucania swej wagi wszystkim przedmiotom i osobom znajdującym się w tym polu; jest obszarem konfliktów i konkurencji, której uczestnicy rywalizują o monopol na szczególny, odpowiedni dla danego pola rodzaj kapitału, np. autorytet” (Bourdieu, Wacquant, 2001, s. 21). Pole jest równocześnie względnie autonomicznym „mikrokomosem” (np. w sferze sztuki) wewnątrz „wszechświata społecznego”, który ma swoją logikę i właściwy sobie rodzaj praktyk i układ stosunków między uczestnikami. Z drugiej strony jest też terenem walki o zajęcie najbardziej korzystnej pozycji i zawłaszczenie możliwie dużego „kapitału”, o jaki toczy się gra na danym polu”. (Szacki, 2002, s. 899-900). Na charakter relacji oraz szansę na „wygraną” w danym polu będą składały się indywidualne habitusy uczestników rozumiane jako zespół tendencji, postaw, dyspozycji uwewnętrznionych, wprowadzonych w sferę ludzkich nawyków, rozciągający się na dziedzinę ocen, emocjonalnych reakcji, stosunku do wartości”. (Bourdieu, Passeron, 1987, s. 13). To, jakich wyborów dokonuje jednostka, w jaki sposób postrzega siebie oraz nadaje znaczenia w ramach systemu wartości i ocen, będzie wypadkową indywidualnego habitusu i cech pola, w ramach którego działa. Przyglądając się zatem obszarowi, na którym działają projektanci, do głównych aktorów należałoby zapewne zaliczyć samych projektantów oraz ich bezpośrednich konkurentów; zleceniodawców i użytkowników (odbiorców); specjalistów odpowiedzialnych za budowanie wizerunku (projektanta, tożsamości firmy, dla której pracuje), badaczy, inżynierów oraz innych pojawiających się w zawodowej przestrzeni designu. Złożoność tego pola bez wątpienia będzie płaszczyzną napięć i konfliktów, zarówno między aktorami, jak i w ramach świata wartości indywidualnego habitusu. Wydaje się więc, że w polu nie ma szans na pełną autonomię, a raczej na jej złudzenie. Czy jednak rzeczywiście projektanci na co dzień odczuwają te napięcia? Aby uzupełnić teoretyczną dyskusję, zaprezentowane zostaną wyniki badań na temat postrzegania zawodu 
projektanta przez pryzmat jego autonomii, przeprowadzone przez autorkę wśród brytyjskich projektantów w trakcie wizyty studyjnej w 2014 roku³

\section{AUTONOMIA PROJEKTANTA - REFLEKSJE BADAWCZE}

Prezentowane badanie zostało zrealizowane wśród profesjonalnych projektantów z jednej z najstarszych europejskich instytucji zatrudniających projektantów - Helen Hamlyn Centre for Design (RCA, London)4. Ogólnym problemem badawczym była charakterystyka zawodu projektanta w perspektywie społecznej odpowiedzialności projektantów. Metodologia tego przedsięwzięcia zakładała celowy dobór respondentów oraz wykorzystanie jakościowej metody badawczej z zastosowaniem techniki pogłębionego wywiadu swobodnego (IDI). Wszystkie rozmowy (6 wywiadów; 5 mężczyzn i 1 kobieta w wieku od 28 do 45 lat) zostały przeprowadzone w Londynie, osobiście przez autora, a każdy trwał około 60 minut. Ze względu na zakres badania zaprezentowane zostaną tylko główne wyniki ${ }^{5}$.

Społeczna odpowiedzialność projektantów to przede wszystkim, zdaniem badanych, wiedza na temat wpływu, jaki decyzje projektowe mogą mieć dla rożnych grup interesariuszy, środowisk w szerokim tego słowa znaczeniu - od konsekwencji dla polityki zrównoważonego rozwoju, przez ekonomiczne skutki, po jednostkowo postrzeganą jakość życia np. w zakresie inkluzji społecznej ochrony zdrowia czy przeciwdziałaniu przestępczości (np. program Design Against Crime).

Ważne jest dla projektantów, aby rozumieli co to znaczy być odpowiedzialnym społecznie z następujących powodów: by doceniali, jaki wpływ ich decyzje projektowe mogq mieć na różne grupy interesariuszy (środowiskowe, ekonomiczne, korzyści dla zdrowia, etc.). Odpowiedzialność oznacza zrozumienie, jak pracq projektanta można zmienić i poprawiać np. stan zdrowia społeczeń-

3 Wizyta studyjna w ramach projektu: Umiędzynarodowienie Krakowskiej Akademii im. Andrzeja Frycza Modrzewskiego (PO KL Działanie 4.1), realizowana pod opieką Dr Jo-Anne Bichard (Post Doctoral Student Supervision from The Helen Hamlyn Centre for Design).

4 HHCD zostało utworzone przez Rogera Colemana i Jeremy Myerson w styczniu 1999 roku celem pokazania roli i możliwości oferowanych przez design w procesie zmian społecznych i demograficznych. Działalność tego centrum koncentruje się wokół designu pojętego przede wszystkim jako narzędzie w poprawie jakości życia ludzkiego. Centrum powstało na bazie wcześniejszej współpracy pomiędzy Helen Hamlyn Trust i jednostki badawczej Royal College of Art w zakresie Design Age, która była aktywna w RCA w latach 1991-1998 (https:/www.rca.ac.uk/research-innovation/ helen-hamlyn-centre/).

5 Z zachowaniem anonimowości respondentów oraz własnym tłumaczeniem rozmów z j. ang. 
stwa, zmieniać postawy w odniesieniu do rosnq̨cej populacji osób starszych, czy w odniesieniu do zagrożeń ekologicznych - czy to poprzez wpływanie na stan wiedzy czy zmianę zachowań. Projektanci powinni próbować zrozumieć społeczeństwo, kierować się empatiq w procesie poznawania ludzi i kultur. (GN)

Jak zatem tworzyć, pracować w sposób niezależny, gdy z założenia praca projektowa jest „zleceniem” spełnienia społecznych oczekiwań?

Projektanci muszq opracować jasne praktyki w zakresie etycznego projektowania, uwzględniajq̨cego zrozumienie, w jaki sposób ich metody pracy i rozwiq̨zania wpływajq na różne grupy zainteresowanych stron zwiq̨zanych z danym projektem. (GN)

Ludzie często na poczq̨tku nam nie ufajq. Sq sceptyczni, bo nigdy nikt ich przedtem o nie pytał o zdanie. Szczególnie w zakresie ochrony zdrowia (np. gdy projektujemy ambulansy), my nie jesteśmy jedynymi ekspertami, dlatego dla nas użytkownicy sq bardzo ważni - lekarze, pacjenci. Musimy przeskakiwać pomiędzy różnymi punktami widzenia. (P)

Projektanci zapytani wprost o poczucie niezależności zawodowej odpowiadali w sposób bardzo opisowy. Żaden z badanych nie potrafił jednoznacznie zadeklarować, czy czuje się niezależny, czy też nie. Zazwyczaj odtwarzali sposób pracy, rolę udziału ostatecznych użytkowników w procesie projektowym czy metody kolekcjonowania niezbędnych danych/informacji. Czasem też porównywali swoją rolę zawodową z rolą artysty. Wówczas zdecydowanie łatwiej było im pokazać, kto może bardziej pozwolić sobie na autonomię (na ogół artystów opisywano jako mających większą niezależność).

Designerzy projektujq dla innych ludzi. Designer może być niezależny, ale to jest zdradliwe. Po pierwsze - trzeba umieć wybrać, który projekt robić. Musisz tego chcieć, bo to ci pomoże zachować względnq niezależność. Twoja praca i kierunek musi też podlegać stale refleksji. (GE)

To jest zawsze jakiś rodzaj balansu pomiędzy oczekiwaniami społecznymi, sugestiami odbiorców a tym, czego my chcemy. Nie potrafię sobie natomiast wyobrazić, aby być całkowicie niezależnym od ich (odbiorców) sugestii i pracować z takiej pozycji. Ale mam świadomość tego, ze my zmieniamy ludzi, że 
chcemy zmieniać ich przyzwyczajenia. To sq pytania ocierajq̨ce się o etykę wobec odbiorcy. (D)

Poczucie niezależności (warunki, aby w ogóle można było o niej myśleć) związane są mocno z ogólnym stanem wiedzy i świadomością społeczną z zakresu designu. Jeśli klienci nie rozumieją, czym jest projektowanie i jakie korzyści przyniesie firmie, wówczas liczba czynników, które ograniczają swobodę projektanta wzrasta. Mówiąc wprost - im większa wiedza zleceniodawcy, tym większa autonomia projektanta.

Tworzymy wiele wspaniałych rzeczy, ale czasami ktoś nas zatrzymuje. Te przeszkody zwykle zwiq̨zane sq z oczekiwaniami różnych zainteresowanych grup. Gdy klienci uczestniczq w naszych procesach, wtedy lepiej zaczynajq rozumieć potrzebę, ale nie zawsze klienci chcq. Mówimy różnymi językami, dla nas np. słowo „prototypować” ma konkretne znaczenie, ale klienci nie zawsze je rozumiejq. Oni oczekują rzeczy, które powstajq zwykle na dalszych etapach. Dla nich prototypowanie to jakiś niepotrzebny punkt. (P)

Często nie nazywamy wszystkiego profesjonalnie, ludzie nie muszq rozumieć naszego języka więc mówimy po prostu o rzeczach ważnych dla nich, nie nazywając tego procesem projektowym. Musimy ludzi prowokować do rozmowy - po prostu pytamy, co o tym myślisz? Główne przeszkody w naszej pracy to to, że ludzie nie widzq wartości design'u; tego, że naprawdę ma moc sprawczq. Kreatywność, innowacja to język design'u, trochę okrutny, którego biznes nie rozumie. My musimy mówić o korzyściach design'u, przekonywać, pokazywać mocne strony. (R)

\section{PODSUMOWANIE}

Trudno jednoznacznie ocenić stopnień niezależności projektantów. Pole, w ramach którego działają, jest dość zróżnicowane zarówno ze względu na liczbę aktorów w nim uczestniczących, jak i rozpiętość często sprzecznych oczekiwań i systemów wartości (np. na linii przedsiębiorca-projektant-klient). Problem niezależności jest dość dobrze znany projektantom i, w pewnym stopniu, wydaje się oswojony. Jak wskazują, większość decyzji projektowych wymaga odnoszenia się do ograniczeń świata oczekiwań społecznych, uwarunkowań prawnych oraz obiektywnych możliwości techniczno-ekonomicznych. Badani designerzy bardzo mocno łączą poczu- 
cie autonomii z odpowiedzialnością społeczną i zarazem wskazują, że wiedza oraz edukacja społeczeństwa z zakresu designu uczyniłaby ich pracę łatwiejszą. Tym samym stopnień autonomii zawodowej zapewne by wzrósł. Relacjonowany fragment badań nie wyczerpuje tematyki, nie pokazuje też różnic w ocenie w ramach poszczególnych specjalności projektowych (inna bowiem może być perspektywa projektanta graficznego, inna projektanta wzornictwa przemysłowego). Mimo że jest zarysowaniem problematyki można przypuszczać, że praca projektanta należy do tych zawodów, u których od samego początków kariery zawodowej pojawiają się wyraźnie problemy autonomii zawodu. Pomimo tego jednak, jak podkreślają liczni autorzy, „ludzie obdarzeni umiejętnością nieszablonowego myślenia są dobrze przystosowani do życia w tym nowym świecie, w którym nic nie trwa wiecznie, wszystko zmienia się w zastraszającym tempie i kilkakrotnie w trakcie kariery trzeba umieć wymyślić siebie na nowo. W życiu i pracy ważne są dziś oczywiście także inne sprawy: etyka, kreatywność i niezawodność. Jeśli będziemy o nich pamiętać, poradzimy sobie w zawodzie projektanta...” (Shaughnessy, 2012, s. 66).

\section{Literatura:}

Bochińska, B., Palczewska, I. (2008). Diagnoza stanu wzornictwa. Raport opracowany na zlecenie Ministerstwa Kultury i Dziedzictwa Narodowego jako jeden z Raportów o Stanie Kultury. Warszawa: Instytut Wzornictwa Przemysłowego.

Bourdieu P., J.-C. Passeron (1987). Reprodukcja. Elementy teorii systemu nauczania. Warszawa: PWN.

Bourdieu P., Wacquant L.J.D. (2001). Zaproszenie do socjologii refleksyjnej. Warszawa: Oficyna Naukowa.

Chojnowska, A. (2002). Psychospołeczne konsekwencje przemian pracy we współczesnym kapitalizmie. Niepublikowana praca magisterska. Warszawa: Instytut Socjologii, UW. Durkheim, E. (1999). O podziale pracy społecznej. Warszawa: PWN.

Krupiński, J. (2014). Filozofia kultury designu. W kręgu myśli Andrzeja Pawłowskiego. Kraków: Wyd. ASP im. Jana Matejki w Krakowie.

Marody, M., Giza-Poleszczuk A. (2004). Przemiany więzi społecznych. Zarys teorii zmiany społecznej. Warszawa: Wydawnictwo Naukowe Scholar.

Papanek, V. (2012). Design dla realnego świata. Środowisko człowieka i zmiana społeczna. Łódź: Recto Verso.

Shaughnessy, A. (2012). Jak zostać dizajnerem i nie stracić duszy. Kraków: Karakter. Simmel, G. (1997). Filozofia pieniądza. Poznań: Wydawnictwo Fundacji Humaniora. Szacki, J. (2002). Historia myśli socjologicznej. Warszawa: PWN.

Sztompka, P., Bogunia-Borowska, M. (red.), (2012). Fotospołeczeństwo. Antologia tekstów z socjologii wizualnej. Kraków: Znak.

Tatarkiewicz, W. (1995). Historia filozofii, t. III. Warszawa: PWN. 
Weber, M. (1994). Etyka protestancka a duch kapitalizmu. Lublin: Test.

The Helen Hamlyn Centre of Design. Pobrane z: https://www.rca.ac.uk/research-innovation/helen-hamlyn-centre/ [20.09.2016].

Modelowy kodeks postępowania zawodowego dla projektantów europejskich. Pobrane z: http://spfp.org.pl/uploads/2012/06/Modelowy_kodeks_postepowania_awodowego_dla_projektantow_europejskich.pdf [20.09.2016].

Kongres Kultury Polskiej. Wzornictwo. Raport. Pobrane z: http://www.kongreskultury. pl/library/File/RaportWzornictwo/wzornictwo_raport_w.pelna(1).pdf [20.09.2016]. 